\title{
Risk factors and presence of antibodies to Brucella canis and smooth Brucella in dogs from the municipality of Araguaína, Tocantins, Brazil
}

\author{
Fatores de risco e presença de anticorpos contra Brucella canis \\ e amostras lisas de Brucella em cães do município de Araguaína, \\ Tocantins, Brasil
}

\author{
Jordana Almeida Santana ${ }^{1}$; Elaine Maria Seles Dorneles²; Valéria de Sá Jayme; \\ Samara da Rocha Galvão"; Silvia Minharro5; Helciléia Santos ${ }^{6}$; \\ Luis Antônio Mathias ${ }^{7}$; Maurício Gautério Dasso ${ }^{8}$; \\ Marcos Bryan Heinemann ${ }^{9}$; Andrey Pereira Lage ${ }^{10^{*}}$
}

\begin{abstract}
Canine brucellosis is an infectious disease of worldwide distribution that can affect dogs, wild canids and man. It is caused by Brucella canis, but dogs can also be infected by smooth Brucella such as $B$. abortus and B. suis. Due to the increasing importance of dogs in our society, the scarcity of information about canine brucellosis in the country and its zoonotic character, the aims of the present study were (i) to conduct a survey on the infection by $B$. canis and smooth Brucella in dogs from the municipality of Araguaína, Tocantins, Brazil, and (ii) to evaluate the risk factors associated with these infections. Sera from 241 dogs were analyzed by agar gel immunodiffusion (AGID) to detect $B$. canis-antibodies, and Buffered Acidified Plate Antigen test (BAPA) and fluorescence polarization assay (FPA) to detect antibodies to smooth Brucella. From the 241 tested dogs, 132 reacted in the AGID and 128 reacted in the BAPA, but only two were positive in FPA. The seroprevalences of B. canis and smooth Brucella infections in dogs in Araguaína were 54.77\% (95\% CI: 48.25 to $61.17 \%$ ) and $0.83 \%$ (95\% CI: 0.10 to $2.97 \%$ ), respectively. The analysis of risk factors showed associations between $B$. canis infection and
\end{abstract}

\footnotetext{
${ }^{1}$ M.e em Ciência Animal, Escola de Veterinária, Universidade Federal de Minas Gerais, UFMG, Belo Horizonte, MG, Brasil. E-mail: jordanaalmeidasantana@gmail.com

${ }^{2}$ M.e em Ciência Animal, Escola de Veterinária, UFMG, Belo Horizonte, MG, Brasil. E-mail: selesdorneles@yahoo.com.br

${ }^{3}$ Prof $^{\mathrm{a}}$ Dr $^{\mathrm{a}}$ em Ciência Animal, Escola de Veterinária e Zootecnia, Universidade Federal de Goiás, UFG, Campus Samambaia, Goiânia, GO, Brasil. E-mail: valeria.mg@uol.com.br

${ }^{4}$ Médica Veterinária, Dr ${ }^{\mathrm{a}}$ em Ciência Animal. Escola de Medicina Veterinária e Zootecnia, Laboratório de Parasitologia, Universidade Federal do Tocantins, UFT, Araguaina, TO, Brasil. E-mail: samavitor@yahoo.com.br

${ }^{5}$ Prof $^{\mathrm{a}} \mathrm{Dr}^{\mathrm{a}}$ em Ciência Animal, Escola de Medicina Veterinária e Zootecnia, Congregação Medicina Veterinária, Universidade Federal do Tocantins, UFT, Araguaina, TO, Brasil. E-mail: silviaminharro@yahoo.com.br

${ }^{6}$ Prof $^{\mathrm{a}} \mathrm{Dr}^{\mathrm{a}}$ em Ciências Veterinária, Escola de Medicina Veterinária e Zootecnia, Congregação Medicina Veterinária, UFT, Araguaina, TO, Brasil. E-mail: hdsantos@uft.edu.br

${ }^{7}$ Prof. Dr. Microbiologia, Faculdade de Ciências Agrárias e Veterinárias, Universidade Estadual Paulista, USP, Jaboticabal, SP, Brasil. E-mail: lmathias@fcav.unesp.br

${ }^{8}$ Pesquisador M.e em Microbiologia Agrícola e do Ambiente, Instituto de Pesquisas Veterinárias Desidério Finamor, Eldorado do Sul, RS, Brasil. E-mail: mauricio-dasso@fepagro.rs.gov.br

${ }_{9}^{9}$ Prof. Dr. em Epidemiologia Experimental Aplicada às Zoonoses, Escola de Veterinária, UFMG, Belo Horizonte, MG, Brasil. E-mail: mabryan@vet.ufmg.br

${ }^{10}$ Prof. Dr. em Bacteriologia, Escola de Veterinária, UFMG, Belo Horizonte, MG, Brasil. E-mail: alage@vet.ufmg.br

* Author for corespondence
} 
vaccination against leptospirosis, and between $B$. canis infection and use of manufactured food. In conclusion, data from the present study showed a low prevalence of infection by smooth Brucella and a widespread and high prevalence of infection by B. canis in the city of Araguaína, Tocantins, Brazil.

Key words: Canine brucelosis, epidemiology, agar-gel immunodiffusion, rose bengal test, fluorescence polarization assay, manufactured food, vaccination

\title{
Resumo
}

\begin{abstract}
A brucelose canina é uma doença infecciosa de distribuição mundial que pode afetar cães, canídeos silvestres e o homem. É causada pela Brucella canis, embora os cães também possam ser infectados por amostras lisas de Brucella, como B. abortus e B. suis. Devido à grande participação dos cães na sociedade, à escassez de informações sobre brucelose canina no país, além de seu caráter zoonótico, os objetivos deste estudo foram (i) realizar um inquérito sobre a infecção de cães por $B$. canis e por amostras lisas de Brucella no município de Araguaína, Tocantins, Brasil, e (ii) avaliar os possíveis fatores de risco associados a estas infecções. Soros de 241 cães foram analisados por Imunodifusão em Gel de Ágar (IDGA) para detecção de anticorpos anti-B. canis, e pelos testes Antígeno Acidificado Tamponado (AAT) e Polarização Fluorescente (PFA) para detectar anticorpos contra amostras lisas de Brucella. Dos 241 cães testados, 132 reagiram na IDGA e 128 reagiram no AAT, mas apenas dois foram positivos na PFA. As soroprevalências das infecções por B. canis e amostras lisas de Brucella em cães de Araguaína foram 54,77\% (95\% IC 95\%; 48,25 a 61,17\%) e 0,83\% (IC 95\%; 0,10 a 2,97\%), respectivamente. Dessa forma, os dados do presente estudo mostraram uma baixa prevalência de infecção por brucelas lisas, mas uma prevalência alta e generalizada de infecção por $B$. canis na cidade de Araguaína, Tocantins, Brasil.

Palavras-chave: Brucelose canina, imunodifusão em ágar gel, teste do antígeno acidificado tamponado, ensaio de polarização fluorescente, ração industrializada, vacinação
\end{abstract}

Canine brucellosis is an infectious disease of worldwide distribution that can affect dogs, wild canids and man. It is a zoonosis caused by Brucella canis, although it can also have smooth Brucella such as B. abortus and B. suis as the etiological agent (CARMICHAEL; GREENE, 1993). Canine brucellosis is systemic, contagious and insidious, without pathognomonic symptoms. The clinical signs are not appropriate to establish a diagnosis, but the infection can be characterized by prolonged bacteremia, abortion in the final third of gestation and persistent vaginal discharge (CARMICHAEL; JOUBERT, 1988). In males, it can lead to epididymitis, prostatitis, orchitis, testicular atrophy and infertility (CARMICHAEL; GREENE, 1993).

In Brazil, the first description of canine brucellosis was in the state of Minas Gerais in 1976 (GODOY; PERES; BARG, 1977) Thereafter, many other surveys were conducted throughout the country, finding frequencies between $0.84 \%$ and 58.3\% (MIRANDA et. al., 2005). Recently our group performed a serologic survey in Araguaína, Tocantins (DORNELES et. al., 2011), and demonstrated a high prevalence of antibodies against B. canis in dogs from this municipality. However, none of the variables evaluated were associated with this high seropositivity.

Therefore, based on that high prevalence of canine brucellosis, its zoonotic aspect, the great losses of the disease on the reproduction of infected dogs, and the increasing importance of dogs in our society, the aims of this study were (i) to conduct another survey on the infection by $B$. canis and smooth Brucella in dogs from municipality of Araguaina, Tocantins, and (ii) to assess new variables as possible risk factors associated with canine brucellosis in the municipality.

The number of animals to be sampled was calculated using a simple sampling strategy (THRUSFIELD, 2004), based on a previous 
prevalence of $44.53 \%$ (DORNELES et. al., 2011), a confidence interval of $95 \%$ and an error of $6.5 \%$, by the software Epi-Info 6.04 (DEAN et. al., 2011). One animal was sampled per household and the households were randomly selected from the list of the Centro de Controle de Zoonoses (CCZ) from the Prefeitura de Araguaína. When the household had no dog or the owner did not give the written consent for the study, the nearest household with a dog was sampled. The period in which data were obtained was from March to October of 2008 when, 246 dogs were sampled. Blood samples were obtained by jugular puncture and, after separation they were stored at $-20^{\circ} \mathrm{C}$ until laboratory analyses. Sera from five animals were lost due to broken tubes, excessive hemolysis or insufficient volume of serum, thus 241 sera were analyzed.

In each of the sampled households a closed questionnaire was applied to obtain data on possible risk factors associated with Brucella spp. infection The variables evaluated included: city region, animal age, animal size, animal sex, age of owner, schooling, housing type, housing time, family income, presence of rodents, accumulation and collection frequency of garbage, presence of sewage system and water, accumulation of water, origin of the animal, vaccination against leptospirosis and feeding type.

Detection of B. canis antibodies was performed by Agar Gel Immunodiffusion technique (AGID), according to Souza et al. (2002), employing soluble B. ovis antigen (Instituto de Pesquisas Veterinárias Desidério Finamor - IPVDF, Brazil). For detection of antibodies to smooth Brucella, Buffered Acidified Plate Antigen test (BAPA) (TECPAR, Brazil) and Fluorescence Polarization Assay (FPA) (Brucella abortus antibody test kit (Brucella FPA), Diachemix, USA) were used as screening and confirmatory tests, respectively (ALTON et. al., 1988; NIELSEN et. al., 2000).

Serological data, prevalence, and associations between variables and infection have been analyzed according to Noordhuizen et al. (1997). Calculation of the associations between seropositivity and the variables related to individual characteristics, animal habits and veterinary care has been carried out by univariate analysis, using the Chi-square and Fisher exact tests with an $\alpha$ error of $5 \%$ (SAMPAIO, 2002). Variables with a $\mathrm{P}$ value $<0.05$ were selected and submitted to prevalence ratio analysis to measure the strength of the association. The confidence intervals for the prevalences were calculated using the exact Clopper-Pearson confidence interval for a single binomial proportion using the $\mathrm{R}$ package binGroup (ZHANG et. al., 2011). Statistical analyses were performed using the software EPIINFO 6.04 (DEAN et. al., 2011).

This study was prepared and implemented according to the regulations and standards of the 196/1996 Resolution of the National Council of Health and approved by the Ethics Committee of the Tropical Medicine Foundation of Tocantins under protocol number 137, approved on March 12, 2008.

From the 241 sera investigated for the presence of antibodies to smooth Brucella, 128 reacted in BAPA, but only two were positive in FPA, showing a prevalence of $0.83 \%$ ( $95 \% \mathrm{CI}: 0.10$ to $2.97 \%$ ). In the AGID to B. canis, 132 dogs have been found positive, resulting in a prevalence of $54.77 \%(95 \%$ CI: 48.25 to $61.17 \%$ ).

The serological evidence observed in the present study indicates that the prevalence of $B$. canis infection remained high and widely spread among dogs from the municipality of Araguaína, Tocantins in 2008, as demonstrated previously by Dorneles et al. (2011), who reported a prevalence of $44.53 \%$ (95\% CI: 39.43 to 49.72 ) with data from 2005. Both results were similar, as the confidence intervals of the observed prevalences overlapped.

Due to the low number of smooth Brucellainfected dogs observed in the present study, only two, risk analysis was not performed for this infection. However, the low prevalence of smooth Brucella seropositive dogs observed may be associated with 
a lower infection risk as those animals were from an urban area and had restricted contact with the main source of smooth Brucella, i.e., aborted fetuses or placentas from infected cows or sows (ALTON et. al., 1988).

The only variables that presented a significant association with $B$. canis infection were vaccination of dogs against leptospirosis (prevalence ratio 1.28; $95 \% \mathrm{CI}$ : 1.02 to 1.60 ) and consumption of manufactured food versus consumption of homemade food (prevalence ratio $1.44 ; 95 \% \mathrm{CI}$ : 1.11 to 1.87$)$. It was observed that vaccination against leptospirosis, and other common diseases of dogs like leishmaniasis, ehrlichiosis, babesiosis, neosporosis and canine distemper, does not induce antibodies that can interfere with $B$. canis serology (OLIVEIRA et. al., 2011). Nevertheless, the practice of vaccination against those diseases was also evidenced as a risk factor for canine brucellosis in another study (BEHZADI; MOGHEISEH, 2011). Both risk factor depicted in the present study did not seem to be directly related to $B$. canis infection. However, they indicate that dog's owners were more concerned with the care of the dogs and probably are exposing the dogs to infection by other factors associated with better caring of the animals as visiting a veterinarian or participating in agglomerations. The large contact among dogs can be a risk factor that contributes indirectly to $B$. canis infection. Transmission can occur by the presence of the agent in aerosols, in foods contaminated by abortion material, vaginal discharges or urine (CARMICHAEL; JOUBERT, 1988) and in sharing fomites (GERMANO et. al., 1987). The association of the caring standard of dogs with $B$. canis infection should be studied more deeply.

Therefore, results from the present study indicate that there is low prevalence of smooth Brucella infection and that $B$. canis infection remains highly widespread in dogs from the municipality of Araguaina, Tocantins. It also suggests that factors associated to higher caring standard could be associated with $B$. canis infection in this population.

\section{Acknowledgments}

This study was supported by Fundação de Amparo à Pesquisa do Estado de Minas Gerais - Fapemig, Fundação de Estudo e Pesquisa em Medicina Veterinária e Zootecnia - FEP-MVZ and Conselho Nacional de Desenvolvimento Científico e Tecnológico - CNPq. JAS, EMSD, MBH and APL received fellowships from $\mathrm{CNPq}$.

\section{References}

ALTON, G. G.; JONES, L. M.; ANGUS, R. D.; VERGER, J. M. Techniques for the brucellosis laboratory. Paris: INRA, 1988. $190 \mathrm{p}$.

BEHZADI, M. A.; MOGHEISEH, A. Epidemiological survey of Brucella canis infection in different breeds of dogs in Fars province, Iran. Pakistan Veterinary Journal, Faisalabad, v. 32, n. 2, p. 234-236, 2011.

CARMICHAEL, L. E.; GREENE, C. E. Brucelosis canina. In: GREENE, C. E. (Ed.). Enfermedades infecciosas perros y gatos. México: Interamericana Mc Graw Hill, 1993. p. 604-616.

CARMICHAEL, L. E.; JOUBERT, J. C. Transmission of Brucella canis by contact exposure. Cornell Veterinary, Ithaca, v. 78, n. 1, p. 63-73, 1988.

DEAN, A. G.; ARNER, T. G.; SUNKI, G. G.; FRIEDMAN, R.; LANTINGA, M.; SANGAM, S.; ZUBIETA, J. C.; SULLIVAN, K. M.; BRENDEL, K. A.; GAO, Z.; FONTAINE, N.; SHU, M.; FULlER, G.; SMITH, D. C.; NITSCHKE, D. A.; FAGAN, R. F. Epi Info ${ }^{\mathrm{TM}}$ : a word processing, database and statistics program for epidemiology on micro-computers. Atlanta: Center for Disease Control, 2011.

DORNELES, E. M. S.; SANTOS, H.; MINHARRO, S.; NASCIMENTO-ROCHA, J. M.; MATHIAS, L. A.; DASSO, M. G.; TIENSOLI, C. D.; HEINEMANN, M. B.; LAGE, A. P. Soroprevalência da infecção por Brucella canis e Brucella abortus em cães do município de Araguaína, Tocantins. Brazilian Journal of Veterinary Research and Animal Science, São Paulo, v. 48, n. 2, p. 167-171, 2011.

GERMANO, P. M. L.; VASCONCELLOS, S. A.; ISHIZUKA, M. M.; PASSOS, E. C.; ERBOLATO, E. B. Prevalência de infecção por Brucella canis em cães da 
cidade de Campinas, SP. Brasil. Revista da Faculdade de Medicina Veterinária e Zootecnia da Universidade de São Paulo, São Paulo, v. 24, n. 1, p. 27-34, 1987.

GODOY, A. M.; PERES, J. N.; BARG, L. Isolamento de Brucella canis em Minas Gerais, Brasil. Arquivos da Escola de Veterinária da Universidade Federal de Minas Gerais, Belo Horizonte, v. 29, n. 1, p. 35-42, 1977.

MIRANDA, K. L.; COTORELlO, A. C. P.; POESTER, F. P.; LAGE, A. P. Brucelose canina. Cadernos Técnicos de Veterinária e Zootecnia, Belo Horizonte, n. 47, p. 6682, 2005.

NIELSEN, K.; LIN, M.; GALL, D.; JOLLEY, M. Fluorescence polarization immunoassay: detection of antibody to Brucella abortus. Methods, San Diego, v. 22, n. 1, p. 71-76, 2000.

NOORDHUIZEN, J. P. T. M.; FRANKENA, K.; VAN DER HOOFD, C. M.; GRAAF, E. A. M. Application of quantitative methods in veterinary epidemiology. Wageningen: Wagenigen Press, 1997. 445 p.
OLIVEIRA, M. Z.; VALE, V.; KEID, L.; FREIRE, S. M.; MEYER, R.; PORTELA, R. W.; BARROUIN-MELO, S. M. Validation of an ELISA method for the serological diagnosis of canine brucellosis due to Brucella canis. Research in Veterinary Science, London, v. 90, n. 3, p. 425-431, 2011.

SAMPAIO, I. B. M. Estatística aplicada à experimentação animal. 2. ed. Belo Horizonte: FEP/MVZ, 2002. 265 p.

SOUZA, L. A.; VIANA, R. C. A.; MICHALICK, M. S. M.; REIS, J. K. P.; LAGE, A. P. Prevalência de infecção por Brucella canis em Belo Horizonte, MG. Revista Brasileira de Medicina Veterinária, Rio de Janeiro, v. 24, n. 3, p. 127-131, 2002.

THRUSFIELD, M. Epidemiologia veterinária. 2. ed. São Paulo: Roca, 2004. 556 p.

ZHANG, B.; BILDER, C.; BIGGERSTAFF, B.; SCHAARSCHMIDT, F. BinGroup: evaluation and experimental design for binomial group testing. 2011. Disponível em: <http://CRAN.R-project.org/ package=binGroup $>$. Acesso em: 12 set. 2012. 
